\title{
EVALUATION OF CASH FLOW REPORT AS AN INVESTMENT DECISION MAKING SUPPORT IN CV. CAHAYA MENTARI IN MAKASSAR
}

\author{
Jafre-V2I2-01
}

\begin{abstract}
The cash flow statement has long been required to be made as part of the company's main financial statements in America based on the Standard of Financial Accounting Statement No.95 Statement of Cash Flows issued by the Financial Accounting Standards Board. For users of financial statements, especially investors, many benefits can be obtained from this report. But many people still don't know this. Usually they only take the data contained in the balance sheet and income statement only to conduct an evaluation in assessing the company's performance. CV. Cahaya Mentari has presented a cash flow statement. The report has been presented well using the indirect method. From the cash flow statement CV. Cahaya Mentari has an increasing net cash flow. However, the company's net cash flow shows a negative number due to a large amount of cash users in investment activities.

Keywords: Operating Cash Flows, Investment Cash Flows, Funding Cash Flows And Investment Decisions
\end{abstract}

\section{INTRODUCTION}

The business world in the current

globalization is developing very rapidly.

Many companies grow with various

business fields and various sizes. Each

company competes tightly with each other.

Every company is required to always look

for ways to win the competition by

managing the business as best as possible

(Brigham et al, 2004). In managing its business activities, the company needs

funds that are not small, especially if the company intends to develop its business. The need for these funds is from two sources, namely internal and external sources.

Lukas (2003) suggests that the company's internal funding sources are sources of funds that are formed or 
produced by the company themselves, for example the company's profits that are not shared or the profits held in the company. While the external funding source of the company is a source of funds derived from additional owner's capital or issuance of new shares, sale of bonds and loans from banks.

Parties who invest their capital in a company or investor if they will make a decision to make an investment, they must first evaluate it. Investors need careful analysis to evaluate whether the investment can produce the expected profit. Before evaluating a company, it is important for an analyst to be familiar with the economic environment of the company which will be analyzed first. Investors need to understand the condition of the company's business, industry development, level of competition and business prospects.

Careful analysis needs to be carried out by prospective investors as a material consideration in making investment decisions. This is done to support decisions taken by potential investors because potential investors must be sure of the benefits that will be gained from the costs incurred in the investments made.

Analysis of financial statements is conducted to determine the company's financial condition. For investors this analysis is a tool in the process of evaluating and projecting the financial situation and results of a project or company. Analysis will be used by investors to make a decision whether they will invest in the company. Sutrisno (2000) suggests that analysis is carried out on the balance sheet and income statement using financial ratios. The ratio is compared from year to year so that the development of the company can be known.

Munawir (2002) stated that the cash flow report had long been made as part of the company's main financial statements in 
America based on the Standard of Financial Accounting Statement No.95 Statement of Cash Flows issued by the Financial Accounting Standards Board. For users of financial statements, especially investors, many benefits can be obtained from this report. But many people still don't know this. Usually they only take the data contained in the balance sheet and income statement only to conduct an evaluation in assessing the company's performance (Padnywati, (2010).

Cash has an important position in the company. Every company in running

\section{THEORETICAL REVIEW}

Cash flow statement is made to show changes in cash and cash equivalents over a certain period. In addition, this cash flow statement also mentions the reason for the change by showing the sources of cash receipts and disbursements (Sari, 2010). The report describes cash inflows and cash outflows in a certain period. This report replaces reports of changes in financial its business needs cash (Jogiyanto, 2003). Cash is needed to finance the company's daily operations, such as buying raw materials, paying wages and salaries. The company must have sufficient cash for current operations and to fulfill its obligations at maturity. For this reason it is important to assess the company about its ability to generate positive cash flow and profit. Assessment is carried out by analyzing the cash flow statement. From the assessment, it will also be known the company's ability to meet its financial obligations and pay dividend.

position or fund statements (Islamiyah, 2012).

Ikbal (2011) proposes that cash flow reports report cash receipts, cash payments and net changes to cash originating from: Operating Activities, Investment and corporate funding for a period in a format that shows how to report a net loss and still hold large capital expenditures or pay 
dividends, or will tell how the company issued or raised debt or ordinary shares or both during this period (Ahmad, 2009).

Darminto (2010) stated that the cash flow statement was prepared with the aim to provide historical information regarding changes in cash and cash equivalents of a company, by classifying cash flows based on operating, investing and financing activities during certain accounting periods. Thus, the main purpose of the cash flow report is to provide users with information about why the company's cash position changes during the accounting period. In addition, the report also shows the effects of infestation and funding activities (Idawati, 2012).

When used in conjunction with other financial statements, such as balance sheets, income statements, retained earnings statements, cash flow statements have usefulness to provide information for (Munawir, 2002):
1. Knowing changes in net assets, financial structure, and ability to influence cash flows.

2. Assess the company's ability to generate cash and cash equivalents.

3. Develop a model to assess and compare the present value of future cash flows from various companies.

4. Can use historical cash flow information as an indicator of the amount of time and concern for future cash flows.

5. Examine the accuracy of estimated future cash flows and determine the relationship between profitability and net cash flows and the impact of price changes.

From the cash flow statement in general is to provide information that supports the data contained in the balance sheet and income statement. So it can be 
said that this cash flow report is more informative. We can find out how cash receipts and expenditures occur in business activities carried out by the company. From these data we will know the historical information of cash inflows and cash outflows of the company. The information obtained from this cash flow report will be very useful for the user. This report provides information about the company's activities in generating cash from operations, maintaining and expanding operating capacity, meeting its financial obligations and paying dividends.

Companies that have good conditions can generate large profits accompanied by increasing positive cash flow. But there are times when companies that have high profits are not followed by a positive cash flow but the cash flow is negative. This can occur because of a number of unrealized revenues. Negative cash flow can mean that the company is unable to manage its wealth well. For this reason, it is necessary to observe the ability to generate profits and the ability to generate positive cash flow.

As previously explained by Rudianto $(2012,198)$, cash flows that occur within a company are divided into three groups of cash sources, namely from operating activities, investment activities and financial activities. In general, there are two methods in preparing cash flow statements, namely direct methods and indirect methods. Both the direct method and the method do not directly divide the company's cash revenue and expenditure sources, into three groups of cash sources (Kasmir, 2012).

a. Direct Method is a method of preparing cash flow statements where detailed cash inflows from operating activities and cash outflows from operating activities. 
The direct method calculates operating cash balances through the difference between cash in from operating income and cash out for the company's operating expenses. Cash flow estimates from investment activities and financial activities are calculated by finding the difference between cash inflows and outflows in each of the sources of the cash source group. Cash flows from each category are summed to produce total net cash flows, which are then added to the cash balance at the beginning of the period so as to produce cash balances at the end of the period.

b. Indirect Method is a method of preparing a cash flow statement in which a reconciliation is made between reported earnings and cash flows. The indirect method starts with business net income and converts into net cash flow from operating activities. While cash flow from investment activities and financial activities is calculated by looking for the difference between cash inflows and cash outflows in each of these cash source groups. Net cash flows from each are then summed to produce total net cash flows, which are then added to the cash balance at the beginning of the period to generate cash balances at the end of the period.

A company must choose one method between the two methods that can be used. Any method used will generate the same cash flow, both in each category and cash balance at the end of the accounting period.

Cash flow transactions are: 
1) Cash Flow Operating Activities

Cash flows from operating activities are primarily from the company's main activities. Cash flow from operating activities comes from all transactions related to net income. Cash flows from these operating activities can come from:

a) Cash inflows from cash receipts for sale of goods and services, receipt of receivables, cash receipts from commissions and other income.

b) Cash flow out of cash payments to suppliers of goods and services, payment of employee salaries, payment of rent, interest payments and other expenses.

Cash flows derived from operating activities are very decisive indicators for companies to generate sufficient cash flow to pay off liabilities, maintain the company's operating ability, to pay dividends or to make investments without relying on outside funding sources.

2) Cash Flow of Investment Activities

Cash flows arising from investing activities reflect cash receipts and disbursements related to resources that aim to generate income and future cash flows.

a) Cash flows from the sale of land, buildings and equipment, intangible assets and other long-term assets and others.

b) Cash outflows from the purchase of fixed assets, intangible assets and other long-term assets and others. 
3. Cash Flow of Funding Assets

Cash flows from financing activities include activities that result in changes in the amount and composition of the company's capital and loans. Cash flows from these financing activities can come from:

a) Cash inflows from issuance of new shares, bonds, notes, hypothokes and other loans.

b) Cash flows out of cash payments to withdraw or penetrate company shares, loan payments and cash dividend payments.

Every company can use a method that is appropriate for the business business in reporting the activity. This cash flow classification will facilitate the use of financial statements in evaluating the relationships that exist within and between these activities.

\section{Benefits of Cash Flow}

The cash flow statement can also be used with other financial statements to provide information for the users to be able to evaluate changes in the company's net assets, the company's financial structure which is about its liquidity and solvency. In addition, it can also be known the ability to influence the amount and time of cash flow in adaptation to changes in changes in circumstances and opportunities.

Heri (2015: 124) stated that cash flow statement data can be used to calculate certain ratios that describe the company's financial strength. Analysis of cash flow statements using components of the cash flow statement and also the balance sheet component and income statement as a ratio analysis tool. 
The benefits derived from this cash

flow report are very useful for investors.

In the investment decision making process, this report can be used as one of the considerations in addition to an analysis of other factors such as business conditions, business competition and the corporate environment.

\section{RESEARCH METHODS}

Location and time of research is a in 2015 - 2017. The analytical method construction company CV. Mentari Light used is descriptive analysis, which is to in Makassar and the study time is January analyze cash flow statements as supporters to March 2018. Types and Sources of data decision making on CV. Mentari Light. are quantitative data, namely data The measurements are:

obtained in the form of Cash Flow Reports

\section{a. Liquidity Ratio}

1. Quik Ratio

Liquidity Ratio consists of two ratios, namely

Current Asset - Supplies

a) Quick ratio=

$$
\text { Current Liability }
$$

b) Current Ratio

\section{Current Asset}

$$
\text { Current ratio }=\overline{\text { Current Liability }}
$$

c) Solvency Ratio

$$
\text { Solvency ratio } \quad=\frac{\text { Total liability }}{\text { Total Asset }}
$$




\section{Profitability Ratio}

This Profitability Ratio consists of three types of ratios, namely:

a) Gross Profit margin

$$
\text { Gross Profit Margin }=\frac{\text { Gross Profit }}{\text { Sales }}
$$

b) Operation Profit Margin $=$

Operation Profit

c) Net Profit Margin $=\frac{\text { Sales }}{\text { Set Profit }}$

\section{RESEARCH RESULTS AND DISCUSSION}

Each company must present a cash

flow statement as part of the company's main financial statements. For that, each company must present a cash flow statement. Companies that previously presented reports on changes in financial position must replace it with a cash flow statement. On CV. Cahaya Mentari's cash flow statement has become part of the company's financial statements.

In the previous chapter it has been explained that cash flow statements can be presented using two methods, namely direct method and indirect method. In this thesis the cash flow report is presented by an indirect method. This method is in accordance with the method used by $\mathrm{CV}$, Cahaya Mentari in presenting its cash flow statement. To compile a cash flow statement, data is needed from the balance sheet, income statement, changes in capital reports and other data. To make the preparation easier 
The cash flow statement has classified the company's activities in three types, namely operating activities, investment activities and financing activities. Therefore, in the preparation it is necessary to consider the classification of types of grains into the right activities. Financial reports obtained from $\mathrm{CV}$. Mentari's light comes from three periods, from 2015-2017. CV. Cahaya Mentari is a company engaged in industry. Based on the data contained in the financial statements, the company has classified its activities into three activities. The classification is as follows:

1. Operational Activities

On CV. Mentari Light which is included in operating activities is an estimate of accounts receivable, inventories, advances for suppliers, prepaid interest, debt, fees that must be paid, tax payable, depreciation, amortization and sales income.
2. Investment Activities

On CV. The Mentari Light which is included in investment activities is the proceeds from the sale of securities, notes receivable, purchase of fixed assets, purchase of securities, increase in other assets, increase in security deposits and reinstatement of fixed assets.

\section{Funding Activities}

On CV. Mentari light which is included in funding activities is the estimation of short-term debt, employee receivables, notes payable, cash dividends, long-term bank loans and lease loans.

$$
\text { Classification of estimates into }
$$
activities will facilitate the preparation of cash flow statements. Presentation is done by an indirect method. The first preparation begins with cash flow from operating activities. The trick is to reconcile net profit or loss with 
depreciation and amortization costs, then with unrealized foreign exchange gains or losses and securities sales profit. After that also calculated the decrease or increase in estimates included in operating activities. These estimates can be seen in the balance sheet and income statement.

Then the second is cash flow from investment activities. To calculate how much cash flow from investment activities is calculated the increase or the calculation of investment estimates. Increase means cash outflows while decreases mean cash inflows. After the calculation is done, it will be known that the cash flow is obtained from or used for investment activities.

Next is cash flow from financing activities. Cash flow calculations from financing activities are carried out by calculating the increase or decrease in estimates related to financing activities. The increase indicates the presence of cash inflows. From these calculations will be known the cash flow obtained from or used for funding activities.

The results of a positive cash flow indicate the existence of cash flows generated from these cash flows. The result of a negative cash flow indicates the cash flow used for the activity. After calculating each activity, the cash flow of each activity is then added. The result of the sum is the company's net cash flow. If the company's net cash flow is positive, it can be said that the company has managed its activities wel

\section{Cahaya Mentari has} presented a cash flow report. The report has been presented well using the indirect method. From the cash flow statement CV. Light Mentari we can see that the company has had a net cash flow that has an increasing number. However, the company's net cash flow shows a negative number due to the presence of users of 
large cash flows in investment activities.

This is because the company purchases large fixed assets and increases in notes receivable.

\section{Financial Ratio Analysis}

Ratio analysis in financial statements uses data taken from the balance sheet and income statement. The ratio analysis to be carried out includes liquidity ratios, solvency ratios, and profitability ratios.

\section{Liquidity Ratio}

a. Quik Ratio
The data that will be used in the analysis comes from three periods so it will get three ratio figures. The ratio numbers are then compared from the ratio. Based on the ratio of the first year ratio, if the second year ratio is lower and the ratio for the third year is higher then it can be said that the ratio tends to rise. If the ratio of the third year ratio is lower then it can be said that the ratio tends to decrease

Liquidity Ratio consists of two ratios, namely

Quick ratio $=\quad$ Current Asset - Supplies

$$
\begin{gathered}
\text { Current Liability } \\
2015=\frac{65.340 .450 .233-19.384 .810 .900}{11.542 .533 .676}=3,9814 \\
2016=\frac{81.586 .149 .964-16.991 .476 .740}{20.460 .090 .500}=3,1571 \\
1017=\frac{150.354 .518 .364-23.709 .845 .111}{220.125}=1,2319
\end{gathered}
$$

From the above ratio, we can see that the ratio tends to decrease. This decrease was due to an increase in the amount of the company's liabilities. 
However, the company ratio rate can be said to be good. The normal normal ratio is between 0.9 to 1 while the company ratio is always above 1 .

b. Current Ratio

$$
\begin{aligned}
\text { Current ratio }= & \frac{\text { Current Asset }}{\text { Current Liability }} \\
2015 & =\frac{65 \cdot 340.450 .233}{11.542 .533 .676}=5,6608 \\
2016 & =\frac{81.586 .149 .964}{20.460 .090 .500}=3,9867 \\
2017 & =\frac{150.354 \cdot 518.364}{102.805 .220125}=1,4625
\end{aligned}
$$

From the calculation of the above ratio we can see that the ratio tends to decrease. This decrease was due to an increase in the amount of the company's current liabilities. But the number of companies can be said to be good. The normal normal ratio is between 1.6 to 1.9 while the ratio of the company is never below 1.6 except in 2015

\section{c. Solvability ratio}

$$
\begin{aligned}
& \text { Solvability ratio }=\frac{\text { Total liability }}{\text { Total Asset }} \\
& 2015=\frac{11.542 .533 .676+8.300 .000 .000}{118.904 .693 .902}=0,169 \\
& 2016=\frac{20.460 .090 .500+8.443 .590 .725}{146.141 .095 .646}=0,1978
\end{aligned}
$$




$$
2017=\frac{102.805 .220 .125+3.145 .488 .297}{242.462 .805 .241}=0,4370
$$

From the calculation of the above

ratio we can see that the ratio tends to rise.

This increase is that companies rely

heavily on outside funding, such as debt.

The company's debt increases in large

d. Profitability Ratio amounts resulting in an increase in the ratio number. However, this ratio is still below the normal normal ratio of 0.57 to

This Profitability Ratio consists of three types of ratios, namely:

$$
\begin{aligned}
\text { Gross Profit Margin ratio } & =\frac{\text { Gross Profit }}{\text { Sales }} \\
2015 & =\frac{20.499 .665 .979}{85.045 .517 .379} \\
2016 & =\frac{29.647 .514 .795}{127.596 .920 .310}=0,2410 \\
2017 & =\frac{53.852121 .621}{233.809 .714 .778}=0,2324
\end{aligned}
$$

From the calculation of the ratio above we can see that the ratio tends to fall. Even though there was a large increase e. Operating Profit Margin ratio in sales. But this was also followed by an increase in sales prices so that gross profit decreased. 


$$
\begin{aligned}
& \text { Operating Profit margin Ratio }=
\end{aligned}
$$

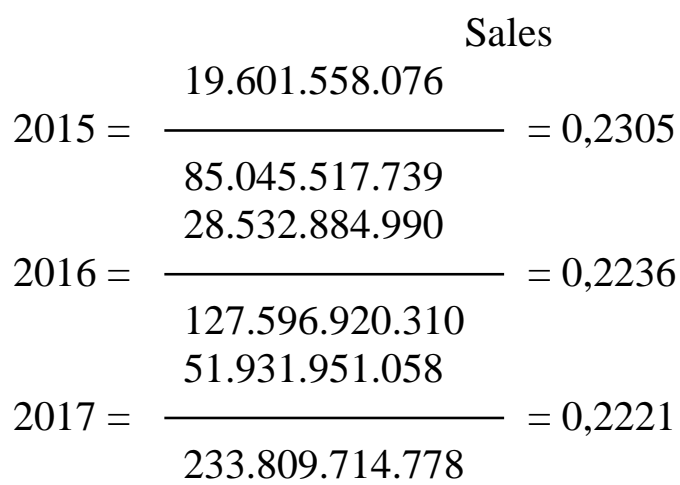

From the calculation of the namely sales costs and general and ratio above we can see that the ratio tends administrative costs. This causes a to fall. This decrease was caused by an decrease in the company's operating increase in the company's business costs, profit.

f. Net Profit Margin Ratio

$$
\begin{aligned}
\text { Net Profit Margin Ratio } & =\frac{\text { Net Profit }}{\text { Sales }} \\
2015 & =\frac{13 \cdot 420 \cdot 673 \cdot 470}{85.045 .517 .379}=0,1578 \\
2016 & =\frac{22.755 \cdot 379.195}{127.596 .920 .310}=0,1783 \\
2017 & =\frac{41.854 \cdot 698.648}{233.809 \cdot 714.778}=0,1790
\end{aligned}
$$

From the calculation of the ratio above, Based on the results of the we can see that the ratio tends to rise. financial ratio analysis that has been This increase was due to an increase in done, it can be concluded that the other income which led to an increase company has a good situation. This can in the company's net profit. be seen from the figures reflected in the 
ratio of liquidity, solvency and profitability.

The liquidity ratio has decreased both in the fast ratio and current ratio. But the liquidity ratio is still good. The company has the ability to meet its current liabilities in the future. This capability is guaranteed by the amount of assets owned by the company and does not depend on the amount of noncurrent assets.

The solvency ratio has increased which indicates that the company's dependence on external funding will increase. This can be seen from the increase in the total debt of the company. However, the ratio figures shown are good.

Profitability ratios have decreased in the ratio of gross profit and operating income. However, there was an increase in the ratio of net a. Acceptance / Profit Quality Ratio income. The decrease in the ratio was due to the increase in sales prices and business costs. Companies must better manage costs in the coming year. Nevertheless, the company is able to increase sales and company profits from year to year.

\section{Cash Flow Analysis}

Cash flow analysis is an analysis carried out on the cash flow statement by comparing the numbers contained therein. Based on this analysis will be seen the company's cash situation. After doing this analysis it will be seen whether the cash flow analysis can support the financial ratio analysis that has been carried out.

Cash flow analysis is carried out using a ratio. This ratio includes the ratio of revenue / profit quality, cash flow adequacy ratio, efficiency ratio, and shor term liquidity. 


$$
\begin{gathered}
\text { Acceptance / Profit Quality Ratio }=\quad \frac{1}{\text { Net Profit }} \\
2015=\frac{13.420 .673 .470}{4.525 .388 .956}=2,9656 \\
2016=\frac{22.755 .379 .195}{16.310 .285 .826}=1,3952 \\
2017=\frac{41.854 .698 .648}{31.352 .544 .905}=1,3350
\end{gathered}
$$

From the calculation of the ratio above we can see that the ratio tends to fall. The higher the ratio means the more cash from operating activities derived from net income. The decrease in ratio is due to a decrease in the amount of cash from operating activities while there is an increase in company profits. This decrease in cash from operating activities may be due to unrealized income.

\section{b. Cash Flow Adequacy Ratio}

This ratio consists of three types, namely

\section{Long-Term Debt Payment Ratio}

$$
\begin{aligned}
& 2015=0 \\
& 2016=\frac{4 \cdot 949 \cdot 625 \cdot 000}{16.310 .285 .286}=0,3035 \\
& 2017=\frac{8.350 \cdot 375.000}{31.352 .544 .905}=0,2663
\end{aligned}
$$


The ratio of long-term debt repayments in 2015 cannot be calculated because the company in 2015 did not make long-term debt payments. So the calculation is only done in 2015 and 2017.
Therefore, the tendency cannot be seen. But from the calculation of the above ratio it can be seen that the 2017 ratio has decreased. This decrease was caused by a decrease in cash from operating activities.

c. Dividend Payment Ratio

$$
\begin{aligned}
& \text { Dividend Payment Ratio } \quad=\quad \text { Dividend } \\
& \text { Kas dari Aktiva Operasi } \\
& \begin{array}{l}
2015=- \\
2016=\frac{4 \cdot 580 \cdot 125 \cdot 000}{16.310 \cdot 285 \cdot 826}=0,2808 \\
2017=\frac{22 \cdot 580 \cdot 016 \cdot 250}{31.352 \cdot 544 \cdot 905}=0,7202
\end{array}
\end{aligned}
$$

Ratio of dividend payment in 2015 cannot be calculated because in that year the company did not pay dividends. So there is only a ratio of 2016 and 2017 so we see the trend.
From the calculation of these two ratios, it can be seen that due to the decrease in cash from operating activities. 
d. Debt Closure Ratio

$$
\begin{aligned}
& \text { Debt Closure Ratio }=\quad \frac{\text { Total Liability }}{\text { Cash from Operating Activities }} \\
& 2015=\frac{11.542 .533 .676+8.300 .000 .000}{4.525 .388 .956}= \\
& 2016=\frac{10.460 .090 .500+8.443 .590 .725}{16.310 .285 .826}=1,7721 \\
& 3017=\frac{102.805 .220 .125+3.145 .488 .297}{31.352 .544 .905}=3,3793
\end{aligned}
$$

From the calculations above we can see that the ratio has decreased. This decrease occurs due to increase. Total

e. Efficiency / Cash Flow Ratio to Sales

$$
\begin{aligned}
& 2015=\frac{4 \cdot 525 \cdot 388 \cdot 956}{85 \cdot 045 \cdot 517 \cdot 739}=0,0532 \\
& 2016=\frac{16 \cdot 310 \cdot 285 \cdot 826}{127 \cdot 596 \cdot 920 \cdot 310}=0,0532 \\
& 2017=\frac{31 \cdot 352 \cdot 544 \cdot 905}{233 \cdot 809 \cdot 714 \cdot 778}=0,0532
\end{aligned}
$$
in cash from operating activities

From the above calculation it can be seen that the ratio tends to decrease.
This decline occurred due to a decrease in cash from a large operating activity. 
f. Short Term Liquidity Ratio

$$
\begin{aligned}
& \text { Short Term Liquidity Ratio }=\frac{\text { Cash Flow From Operations }}{\text { Average Current Liabilities }} \\
& 2015=\frac{4.525 .388 .956}{(5.117 .337 .551+11.542 .533 .676): 2}=0,1358 \\
& 2016=\frac{4.525 .388 .956}{(11.542 .533 .676 .+20.460 .090 .500): 2}=0,1358 \\
& \frac{31.325 .544 .905}{(20.460 .090 .500+102.805 .202 .125): 2}=0,1358
\end{aligned}
$$

From the calculation

of the ratio above we can see that the

ratio tends to fall. This decrease occurred due to a decrease in cash from operating activities.

\section{g. Cash Flow Adequacy Ratio}

Cas Flow Adequacy Ratio =

$$
\text { Cash Flow From Operations }
$$

$$
\text { Capital Expenditures + Inventori Addition + Cash }
$$

$$
\begin{aligned}
& 2014=\frac{4.525 .388 .956}{27.531 .462 .120+9.224 .355 .281+0}=0,1231 \\
& 16.310 .285 .826 \\
& 2016=\overline{11.270 .258 .346+2.939 .334 .160+580.125 .000}=1,7247 \\
& 11.270 .258 .346+2.939 .334 .160+580.125 .000 \\
& \text { 31.352.544.905 } \\
& 2017=\longrightarrow=0,4373 \\
& 42.403 .423 .377+6.718 .368 .371+22.580 .016 .250
\end{aligned}
$$

From the calculation of the ratio above we can see that the ratio tends to fall.
This decrease was due to a decrease in cash from operating activities. 
However, the ratio of the ratio shows a good ratio. A normal normal ratio is 1 . In 2016 the ratio shows a good number of more than 1 .

Based on the calculation of the liquidity ratio in financial ratios, the ratio numbers tend to fall. The decrease in the ratio occurs both in the fast ratio and in the current ratio. This is in accordance with the ratio shown in the ratio of short term liquidity has decreased. The ratio of short-term liquidity and liquidity ratios shows that in the company there is an increase in the amount of large debt that is not offset by the amount of assets and cash flows from activities.

The solvency ratio in financial ratios has a ratio that tends to rise. Likewise, the ratio of the adequacy of cash flows and debt closure shows a declining ratio. If a comparison is made between the two, it can be said that in the company there is an increase in the amount of debt that is not offset by the amount of assets and cash flows from operating activities.

\section{Profitability ratios in financial} ratios have decreased in gross profit and operating income. This decrease was caused by an increase in sales prices and operating costs, namely sales costs and general and administrative costs. But in the ratio of net income, the ratio increases. This shows that the company is still able to generate increased profits from year to year.

The sales ratio and revenue / profit quality ratio show a declining number. If a comparison is made between profitability ratios and income / profit quality ratios and sales ratios, it can be said that in the company there is an increase in net income that is not offset by cash flows from operating activities. The decrease in cash flows from 
operating activities can be caused by

\section{CONCLUSION}

Based on the results of research and discussion, the following the authors present the following conclusions:

1. Based on the discussion, the authors draw the conclusion that the cash flow statement in each activity shows the company's net cash flow is positive, it can be said that the company has managed activities in the company well. unrealized income.

2. CV. Cahaya Mentari has presented a cash flow statement. The report has been presented well using the indirect method. From the cash flow statement CV. Cahaya Mentari has an increasing net cash flow. However, the company's net cash flow shows a negative number due to a large amount of cash users in investment activities.

\section{BIBLIOGRAPHY}

Agnes Sawir. 2005. Analisis Kinerja Keuangan Dan Perencanaan Keuangan Perusahaan, Gramedia Pustaka Utama, Jakarta.

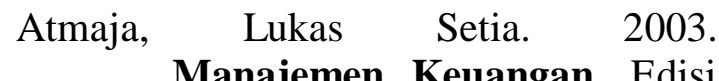
Manajemen Keuangan. Edisi Revisi dilengkapi Soal-Jawab. Yogyakarta: ANDI

Brigham, Eugene $\mathrm{F}$ dan Houston, Joel F, 2004.Dasar-Dasar Manejemen Keuangan. Edisi ke-
10 Terjemahan. Salemba Empat: Jakarta.

Darminto. 2010. Pengaruh Faktor Eksternl dan Berbagai Keputusan Keuangan Terhadap Nilai Perusahaan. Jurnal Aplikasi manajemen, Vol 8 No 1.

Hery. 2012. Analisis Laporan Keuangan. PT. Bumi Aksara Jakarta

Ikbal, Muhammad. 2011, Pengaruh Profitabilitas dan Kepemilikan 
Insider terhadap Nilai

Perusahaan dengan Kebijakan

Utang dan Kebijakan Dividen Sebagai variabel Moderat.

Simposium Nasional Akuntansi XIV.

Jogiyanto, 2003, Teori Portofolio dan Analisis Investasi, BPFE. Yogyakarta.
Munawir, 2002, Analisis Laporan Keuangan, Liberty, Yogyakarta.

Riyanto, Bambang. 2001. Dasar-Dasar Pembelanjaan Perusahaan. Edisi Keempat. Yogyakarta: BPFE.

Sutrisno, 2000. Manajemen Keuangan.

Yogyakarta: Ekonisia 